\title{
A novel mutation of GDAP1 associated with Charcot-Marie- Tooth disease in three Italian families: evidence for a founder effect
}

\author{
E Di Maria, R Gulli, P Balestra, D Cassandrini, S Pigullo, L Doria-Lamba, M Bado, A Schenone, \\ F Ajmar, P Mandich, E Bellone
}

J Neurol Neurosurg Psychiatry 2004;75:1495-1498. doi: 10.1136/jnnp.2003.028100

\begin{abstract}
Background: Mutations in a gene encoding a novel protein of unknown function-the ganglioside-induced differentiation-associated protein 1 gene (GDAPI)-are associated with the autosomal recessive Charcot-Marie-Tooth disease type 4A (CMT4A).

Objective: To investigate the role of GDAPI mutations in causing autosomal recessive neuropathies in an Italian population.

Methods and results: 76 patients with severe early onset polyneuropathy and possible autosomal recessive inheritance were screened for mutations. $A T>G$ transversion (c.347 T>G) at codon 116 (M1 16R) was detected in four affected subjects from three apparently unrelated families. All patients had early onset of disease with pronounced foot deformities and impaired walking. Neurophysiological studies showed an extremely variable expression. Sural nerve biopsies revealed signs of both de-remyelination and axonal impairment, the most prominent feature being a severe loss of larger fibres. Haplotype analysis of the GDAP1 locus demonstrated a common disease haplotype.

Conclusions: The association of the mutation with a common haplotype suggested a common ancestor.
\end{abstract}

C harcot-Marie-Tooth disease (CMT) comprises a group of clinically and genetically heterogeneous disorders of the peripheral nervous system characterised by chronic distal weakness, progressive muscular atrophy, and sensory loss in the distal extremities. ${ }^{1}$ On the basis of neuropathological and electrophysiological features, CMT falls into two main subtypes - the demyelinating form, CMTl, and the axonal type, CMT2. CMT1 is characterised by reduced nerve conduction velocities (with values of $<38 \mathrm{~m} / \mathrm{s}$ for the median motor nerve), segmental de- and remyelination, and onion bulb formation. In CMT2, nerve conduction velocities are normal or near normal and nerve pathology shows signs of axonal impairment. ${ }^{2}$ The mode of inheritance can be autosomal dominant, $\mathrm{X}$ linked, or recessive (autosomal recessive Charcot-Marie-Tooth disease, ARCMT). For the demyelinating forms of ARCMT, seven genes have been identified so far. ${ }^{3-10}$ Recently, mutations of the gangliosideinduced differentiation-associated protein l gene (GDAPl) have been reported as causing a severe early onset autosomal recessive CMT (CMT4A). To date, several GDAPl mutations have been found to be associated with a wide spectrum of clinical and electrophysiological features. ${ }^{11-20}$ We investigated the role of GDAPI mutations in a cohort of Italian patients and identified a novel missense mutation in three families.

\section{METHODS}

Seventy six unrelated patients, originating from different Italian regions, were selected on the basis of a severe progressive motor and sensory polyneuropathy with onset in the first decade, absence of clinical and electrophysiological signs in either parent, and exclusion of mutations in the PMP22, MPZ, GJB1, and EGR2 genes.

The entire coding region of GDAPl, including the exonintron boundaries, ${ }^{12}$ was screened for mutation by single strand conformation polymorphism (SSCP) analysis. ${ }^{21}$ Direct sequencing of the abnormal polymerase chain reaction (PCR) fragments was carried out on an automated DNA sequencer. Haplotype analysis was done with short tandem repeat (STR) markers D8S551, D8S1829, and D8S441. ${ }^{12}$ In addition, a single nucleotide polymorphism (rs3739345), located within intron 1 of the GDAPI gene, was selected by inspecting the GenBank SNP database. Genotyping of rs3739345 was carried out by direct sequencing of the PCR fragment. The M116R mutation was examined in 157 normal unrelated subjects through primer extension analysis. Detailed protocols are available on request. Neurological, electrophysiological, and neuropathological evaluations were carried out according to standard procedures.

\section{RESULTS}

The series of CMT patients was screened for mutations in the entire coding region of GDAPl by SSCP analysis. The PCR fragment encompassing GDAPI exon 4 showed two different electrophoretic profiles in both patients and normal controls. Direct sequencing of the exon 4 revealed a $\mathrm{G}>\mathrm{T}$ transversion at nucleotide 507 (c.507G $>$ T), which did not alter the corresponding serine codon 169, thus revealing the Serl69Ser polymorphism already described. ${ }^{14}$ SSCP analysis of exon 3 detected an altered pattern with respect to normal controls in three unrelated index patients. Direct sequencing of the exon 3 revealed a homozygous $\mathrm{T}>\mathrm{G}$ transversion at position 347 (c.347T $>\mathrm{G}$ ) predicting an amino acid change from methionine to arginine at codon 116 (Ml16R). Four individuals belonging to three families carried the homozygous Ml16R mutation (fig 1). Their unaffected parents were heterozygous carriers. The Ml16R mutation co-segregated with the disease in all pedigrees and was not revealed in 314 control chromosomes.

As the same GDAPI mutation was present in three apparently unrelated families and as all patients originated from one Italian region (Campania), we predicted that the mutation might be inherited from a common ancestor. To

Abbreviations: ARCMT, autosomal recessive Charcot-Marie-Tooth disease; CMT, Charcot-Marie-Tooth disease; GDAPI, gangliosideinduced differentiation-associated protein 1 
Table 1 Electrophysiological features of the patients with the M116R mutation

\begin{tabular}{|c|c|c|c|c|c|c|c|c|c|c|}
\hline \multirow[b]{2}{*}{ Patient } & \multirow{2}{*}{$\begin{array}{l}\text { Age at onset } \\
\text { (years) }\end{array}$} & \multirow{2}{*}{$\begin{array}{l}\text { Age at examination } \\
\text { (years) }\end{array}$} & \multicolumn{2}{|c|}{ Median nerve } & \multicolumn{2}{|c|}{ Peroneal nerve } & \multicolumn{2}{|c|}{ Median nerve } & \multicolumn{2}{|c|}{ Sural nerve } \\
\hline & & & MNCV & CMAP & MNCV & CMAP & SNCV & SNAP & SNCV & SNAP \\
\hline $\begin{array}{l}\text { Family } 1 \\
\text { II:2 }\end{array}$ & 1 & $\begin{array}{l}4 \\
12 \\
14\end{array}$ & $\begin{array}{l}33 \\
29 \\
\text { NE }\end{array}$ & $\begin{array}{l}1.9 \\
1.3 \\
\mathrm{NE}\end{array}$ & $\begin{array}{l}\mathrm{NE} \\
\mathrm{NE} \\
\mathrm{NE}\end{array}$ & $\begin{array}{l}\mathrm{NE} \\
\mathrm{NE} \\
\mathrm{NE}\end{array}$ & $\begin{array}{l}\mathrm{NE} \\
\mathrm{NE} \\
\mathrm{NE}\end{array}$ & $\begin{array}{l}\mathrm{NE} \\
\mathrm{NE} \\
\mathrm{NE}\end{array}$ & $\begin{array}{l}\mathrm{NE} \\
\mathrm{NE} \\
\mathrm{NE}\end{array}$ & $\begin{array}{l}\mathrm{NE} \\
\mathrm{NE} \\
\mathrm{NE}\end{array}$ \\
\hline $\begin{array}{l}\text { Family } 2 \\
\text { II:2 }\end{array}$ & 7 & $\begin{array}{l}13 \\
14 \\
16\end{array}$ & $\begin{array}{l}50 \\
51.2 \\
55\end{array}$ & $\begin{array}{l}2.4 \\
2 \\
1\end{array}$ & $\begin{array}{l}\mathrm{NE} \\
\mathrm{NE} \\
\mathrm{NE}\end{array}$ & $\begin{array}{l}\mathrm{NE} \\
\mathrm{NE} \\
\mathrm{NE}\end{array}$ & $\begin{array}{l}46.4 \\
46.1 \\
47.4\end{array}$ & $\begin{array}{l}8 \\
3 \\
1\end{array}$ & $\begin{array}{l}\mathrm{ND} \\
47.2 \\
\mathrm{NE}\end{array}$ & $\begin{array}{l}\mathrm{ND} \\
3 \\
\mathrm{NE}\end{array}$ \\
\hline $\begin{array}{l}\text { Family } 2 \\
\text { II:3 }\end{array}$ & 7 & $\begin{array}{l}7 \\
9\end{array}$ & $\begin{array}{l}51 \\
50.3\end{array}$ & $\begin{array}{l}3.6 \\
3\end{array}$ & $\begin{array}{l}\text { NE } \\
\text { NE }\end{array}$ & $\begin{array}{l}\text { NE } \\
\text { NE }\end{array}$ & $\begin{array}{l}50.4 \\
54.9\end{array}$ & $\begin{array}{l}5 \\
4\end{array}$ & $\begin{array}{l}42.9 \\
47.6\end{array}$ & $\begin{array}{l}4 \\
2\end{array}$ \\
\hline $\begin{array}{l}\text { Family } 3 \\
\text { II:1 }\end{array}$ & 2 & $\begin{array}{l}9 \\
20\end{array}$ & $\begin{array}{l}29.4 \\
\mathrm{NE}\end{array}$ & $\begin{array}{l}<0.1 \\
\mathrm{NE}\end{array}$ & $\begin{array}{l}\text { ND } \\
\text { NE }\end{array}$ & $\begin{array}{l}N D \\
\text { NE }\end{array}$ & $\begin{array}{l}40.5 \\
38\end{array}$ & $\begin{array}{l}3 \\
2\end{array}$ & $\begin{array}{l}\mathrm{ND} \\
\mathrm{NE}\end{array}$ & $\begin{array}{l}N D \\
\text { NE }\end{array}$ \\
\hline
\end{tabular}

CMAP, compound muscle action potential amplitude $(\mathrm{mV}) ; \mathrm{MNCV}$, motor nerve conduction velocity $(\mathrm{m} / \mathrm{s}) ; \mathrm{ND}$, not done; $\mathrm{NE}$, not elicitable; SNAP, sensory nerve action potential $(\mu \mathrm{V})$; SNCV, sensory nerve conduction velocity $(\mathrm{m} / \mathrm{s})$.

reflexes were absent in the legs. Disabilities showed rapid progression. At age 26 she had distal muscle weakness in all four limbs and evident small hand muscle involvement, with atrophy and loss of dexterity. Walking was possible only with external support.

All patients were examined electrophysiologically in at least two different stages of the disease course. The results of the electrophysiological study are summarised in table 1. Sural nerve biopsies were done at the age of 5, 15, and 9 years in patients II:2 (family No 1), II:2 (family No 2), and II:1 (family No 3), respectively. The neuropathological features were similar in all patients: there was a loss of myelinated axons, ranging from mild to severe, with a more prominent impairment of larger fibres. Several of the remaining fibres showed a reduction in myelin thickness. Sometimes thinly myelinated axons were surrounded by Schwann cell processes concentrically organised to form small onion bulbs. Occasionally, clusters of small regenerating fibres were found (fig 1).

\section{DISCUSSION}

In this report we describe a novel pathogenic mutation (M116R), segregating in three apparently unrelated Italian pedigrees from a restricted geographical area. This mutation was found to be associated with a common haplotype, suggesting a common ancestor.

Consistent with the phenotypes previously associated with GDAP1 mutations, ${ }^{11-20}$ patients with the Ml16R mutation showed an early onset of the disease and a progression of muscular atrophy leading to loss of independent ambulation within the third decade. Small hand muscle involvement with atrophy and loss of dexterity was evident in all patients in the second decade. None presented with vocal cord dysfunction, which has been described only in patients carrying the Q163X variant. ${ }^{12}{ }^{15}{ }^{17}$ However, genotype-phenotype correlation is hampered by the limited number of GDAPI mutations so far reported ${ }^{11-20}$ and by uncertainty about the function of the GDAPl protein. The Mll6R missense mutation is located inside the glutathione S-transferase domain I, which is supposed to be responsible for the functional properties of the protein. ${ }^{22}$ Whether GDAPl is involved in signal transduction or cellular detoxification, as has been suggested, ${ }^{18}{ }^{23}$ it is likely that the mutated protein is not able to ensure the complex interactions between
Schwann cells and neurones, determining the severe, early onset peripheral neuropathy observed in the patients.

The electrophysiological and neuropathological studies disclosed signs of both de-remyelination and axonal impairment, as previously reported in GDAPl gene mutations. ${ }^{11-20}$ Either in cases with slowed nerve conduction velocities (patients from family 1 and family 3 ), or in the presence of a normal nerve conduction velocity (patients from family 2 ), the amplitude of both the motor and sensory action potentials showed a tendency to decrease over time in all the nerves examined, suggesting that the clinical worsening is mainly the result of an ongoing axonal degeneration, as observed in other forms of CMT. ${ }^{24}$

In the present study, 3.9\% of subjects (three of 76) carried a novel GDAPI homozygous mutation. This frequency, however, is biased by the geographical origin of the patients and it probably arises from a founder effect, as suggested by the absence of Ml16R carriers in a large sample of normal individuals. Further studies on independent sample series are warranted to estimate the disease allele frequency and suggest the criteria for targeted mutation screening of GDAP1. At present, given the lack of specific criteria for CMT4A, GDAPI might be investigated in peripheral neuropathies with probable autosomal recessive inheritance.

\section{ACKNOWLEDGEMENTS}

This work was supported by Ministero della Salute RF2002 to PM and EB, by MIUR 2002 to FA, and by Telethon 11 UP02169 and FISM 2001R59 to AS. The Department of Neuroscience, Ophthalmology and Genetics participates in the European CMT Consortium with the Sections of Medical Genetics and Neurology. AS works at the Centre of Excellence for Biomedical Research (CEBR), University of Genova, Italy. We wish to thank Dr F Palau, Dr N Ammar, Dr E Nelis, and Dr $\mathrm{V}$ Timmermann for sharing data and helpful discussion. We are grateful to the patients and their relatives for their collaboration. The clinical and technical assistance of Dr I Fiocchi and Mr G Gianfranco Gherardi is gratefully acknowledged.

\section{Authors' affiliations}

E Di Maria, R Gulli, P Balestra, D Cassandrini, S Pigullo, A Schenone, F Ajmar, P Mandich, E Bellone, Department of Neuroscience, Ophthalmology and Genetics, University of Genova, Genova, Italy L Doria-Lamba, U.O. e Cattedra di Neuropsichiatria Infantile, Institute "G Gaslini", Genova

M Bado, Neuromuscular Diseases Unit, Department of Paediatrics, Institute "G Gaslini" 


\section{Competing interests: none declared}

Correspondence to: Dr E Bellone, Department of Neuroscience, Ophthalmology and Genetics, Section of Medical Genetics, University of Genova, c/o DIMI - Viale Benedetto XV, 616132 Genova, Italy; ebellone@unige.it

Received 16 September 2003

In revised form 8 January 2004

Accepted 13 January 2004

\section{REFERENCES}

1 Dyck PJ. Inherited neuronal degeneration and atrophy affecting peripheral motor, sensory, and autonomic neurons. In: Dyck PJ, Thomas PK, Lambert EH eds. Peripheral neuropathy. Philadelphia: WB Saunders, 1975:825-67.

2 Harding AE, Thomas PK. Genetic aspects of hereditary motor and sensory neuropathy (types I and II). J Med Genet 1980;17:329-36.

3 Warner LE, Mancias P, Butler IJ, et al. Mutations in the early growth response 2 (EGR2) gene are associated with hereditary myelinopathies. Nat Genet 1998; 18:382-4.

4 Bolino A, Muglia M, Conforti FL, et al. Charcot-Marie-Tooth type $4 \mathrm{~B}$ is caused by mutations in the gene encoding myotubularin-related protein-2. Nat Genet 2000;25:17-19.

5 Kalaydjieva L, Gresham D, Gooding R, et al. N-myc downstream-regulated gene 1 is mutated in hereditary motor and sensory neuropathy-Lom. Am J Hum Genet 2000;67:47-58.

6 Boerkoel CF, Takashima H, Stankiewicz P, et al. Periaxin mutations cause recessive Dejerine-Sottas neuropathy. Am J Hum Genet 2001;68:325-33

7 Guilbot A, Williams A, Ravise N, et al. A mutation in periaxin is responsible for CMT4F, an autosomal recessive form of Charcot-Marie-Tooth disease. Hum Mol Genet 2001; 10:415-21.

8 Senderek J, Bergmann C, Weber S, et al. Mutation of the SBF2 gene, encoding a novel member of the myotubularin family, in Charcot-Marie-Tooth neuropathy type 4B2/11 p15. Hum Mol Genet 2003;12:349-56.

9 Azzedine H, Bolino A, Taieb T, et al. Mutations in MTMR13, a new pseudophosphatase homologue of MTMR2 and Sbfl, in two families with an autosomal recessive demyelinating form of Charcot-Marie-Tooth disease associated with early-onset glaucoma. Am J Hum Genet 2003;72:1141-53.

10 Senderek J, Bergmann C, Stendel C, et al. Mutations in a gene encoding a novel SH3/TPR domain protein cause autosomal recessive Charcot-MarieTooth type 4C neuropathy. Am J Hum Genet 2003;73:1106-19.
11 Baxter RV, Ben-Othmane K, Rochelle JM, et al. Ganglioside-induced differentiation-associated protein-1 is mutant in Charcot-Marie-Tooth disease type 4A/8q21. Nat Genet 2002;30:21-2.

12 Cuesta A, Pedrola L, Sevilla T, et al. The gene encoding ganglioside-induced differentiation-associated protein 1 is mutated in axonal Charcot-Marie-Tooth type 4A disease. Nat Genet 2002;30:22-5.

13 Nelis E, Erdem S, Van-Den-Bergh PY, et al. Mutations in GDAP1: autosomal recessive CMT with demyelination and axonopathy. Neurology 2002:59:1865-72.

14 Senderek J, Bergmann C, Ramaekers VT, et al. Mutations in the gangliosideinduced differentiation-associated protein-1 (GDAP1) gene in intermediate type autosomal recessive Charcot-Marie-Tooth neuropathy. Brain 2003; 126:642-9.

15 Boerkoel CF, Takashima H, Nakagawa M, et al. CMT4A: identification of a Hispanic GDAP1 founder mutation. Ann Neurol 2003;53:400-5.

16 Birouk N, Azzedine H, Dubourg O, et al. Phenotypical features of a Moroccan family with autosomal recessive Charcot-Marie-Tooth disease associated with the S194X mutation in the GDAP1 gene. Arch Neurol 2003;60:598-604

17 Sevilla T, Cuesta A, Chumillas MJ, et al. Clinical, electrophysiological and morphological findings of Charcot-Marie-Tooth neuropathy with vocal cord palsy and mutations in the GDAP1 gene. Brain 2003;126:2023-33.

18 De Sandre-Giovannoli A, Chaouch M, Boccaccio I, et al. Phenotypic and genetic exploration of severe demyelinating and secondary axonal neuropathies resulting from GDAPI nonsense and splicing mutations. J Med Genet 2003;40:e87.

19 Ammar N, Nelis E, Merlini L, et al. Identification of novel GDAP1 mutations causing autosomal recessive Charcot-Marie-Tooth disease. Neuromuscul Disord 2003;13:720-8.

20 Azzedine $H$, Ruberg $M$, Ente $D$, et al. Variability of disease progression in a family with autosomal recessive CMT associated with a S194X and new R310Q mutation in the GDAP1 gene. Neuromuscul Disord 2003;13:341-6.

21 Mandich P, Montera M, Bellone E, et al. Three novel mutations in the Von Hippel-Lindau tumour suppressor gene in Italian patients. Hum Mut 1998; 1:S268-70

22 Marco A, Cuesta A, Pedrola L, et al. Evolutionary and structural analyses of GDAP1, involved in Charcot-Marie-Tooth disease, characterize a novel class of glutathione transferase-related genes. Mol Biol Evol 2003;21:176-87.

23 Liu H, Nakagawa T, Kanematsu T, et al. Isolation of 10 differentially expressed cDNAs in differentiated Neuro2a cells induced through controlled expression of the GD3 synthase gene. J Neurochem 1999;72:1781-90.

24 Garcia A Combarros O, Calleja J, et al. Charcot-Marie-Tooth disease type $1 \mathrm{~A}$ with $17 p$ duplication in infancy and early childhood: a longitudinal clinical and electrophysiologic study. Neurology 1998;50:1061-7. 